J. Dairy Sci. 98:3351-3365

http://dx.doi.org/10.3168/jds.2014-8821

(C) American Dairy Science Association ${ }^{\circledR}, 2015$.

\title{
Metabolism of early-lactation dairy cows as affected by dietary starch and monensin supplementation
}

\author{
M. M. McCarthy, ${ }^{*}$ T. Yasui, ${ }^{*}$ C. M. Ryan, ${ }^{*}$ S. H. Pelton, ${ }^{*}$ G. D. Mechor, $†$ and T. R. Overton ${ }^{* 1}$ \\ *Department of Animal Science, Cornell University, Ithaca, NY 14853 \\ †Elanco Animal Health, Greenfield, IN 46140
}

\begin{abstract}
The objective of this study was to evaluate the effect of dietary starch content and monensin (MON) on metabolism of dairy cows during early lactation. Before parturition, primiparous $(\mathrm{n}=21)$ and multiparous $(\mathrm{n}$ $=49$ ) Holstein cows were fed a common controlledenergy close-up diet with a daily topdress of either 0 or $400 \mathrm{mg} / \mathrm{d}$ monensin. From d 1 to 21 postpartum, cows were fed a high-starch (HS; $26.2 \%$ starch, $34.3 \%$ neutral detergent fiber, $22.7 \%$ acid detergent fiber, $15.5 \%$ crude protein) or low-starch (LS; $21.5 \%$ starch, $36.9 \%$ neutral detergent fiber, $25.2 \%$ acid detergent fiber, $15.4 \%$ crude protein) total mixed ration with a daily topdress of either $0 \mathrm{mg} / \mathrm{d}$ monensin $(\mathrm{CON})$ or 450 $\mathrm{mg} / \mathrm{d}$ monensin (MON), continuing with prepartum topdress assignment. From d 22 through 63 postpartum, all cows were fed HS and continued with the assigned topdress treatment until d 63. Cows fed HS had higher plasma glucose and insulin and lower nonesterified fatty acids (NEFA) than cows fed LS during d 1 to 21 postpartum. Cows fed LS had elevated early-lactation $\beta$-hydroxybutyrate (BHBA) compared with cows fed HS. Cows fed HS had greater insulin resistance and increased plasma haptoglobin in the early lactation period. There was no effect of MON on postpartum plasma NEFA. Cows fed MON had higher plasma glucose compared with CON cows, which was driven by a MON $\times$ parity interaction in which primiparous cows fed MON had greater plasma glucose concentrations than cows fed CON. Cows fed MON had lower plasma BHBA compared with CON, which was contributed to by a MON $\times$ parity interaction in which primiparous cows fed MON had lower BHBA concentrations than CON. Starch treatment had no effect on overall liver triglyceride content. Primiparous cows fed MON had increased liver triglyceride content compared with CON
\end{abstract}

Received September 4, 2014.

Accepted February 5, 2015.

${ }^{1}$ Corresponding author: tro2@cornell.edu primiparous cows, and multiparous cows fed MON had decreased liver triglyceride content compared with CON cows. Multiparous cows fed LS with MON had higher liver glycogen content than multiparous cows fed the LS without MON, with no effect of MON treatment for multiparous cows fed HS. There was no effect of starch or MON treatment on liver capacity to oxidize propionate to $\mathrm{CO}_{2}$, and effects of starch on gluconeogenesis were not significant. Cows fed MON tended to have greater capacity to convert propionate to glucose than CON. Supplementation with MON increased the ratio of glucose to $\mathrm{CO}_{2}$, which indicated that cows fed MON had a greater propensity to convert propionate to glucose. Overall, cows fed more propiogenic diets in early lactation (high starch or monensin) exhibited improved energy metabolism during early lactation.

Key words: early lactation, metabolism, starch, monensin

\section{INTRODUCTION}

Many postpartum metabolic disorders are the result of insufficient energy intake in the period immediately surrounding parturition. After calving, DMI is insufficient to support the high milk production of early lactation and results in a state of negative energy balance (EB), leading to greater mobilization of adipose tissue and release of NEFA into circulation to be metabolized by the liver (Drackley, 1999). Higher energy intake postpartum results in lower circulating NEFA (Andersen et al., 2004; Rabelo et al., 2005) and has been associated with improved health (Ospina et al., 2010), performance (Andersen et al., 2003; Rabelo et al., 2003), and less severe postpartum negative EB (Ingvartsen and Andersen, 2000).

The fermentation of starch in the rumen favors production of propionate, which is the main precursor for hepatic glucose production, and supplementation with monensin (an ionophore) has been shown to increase ruminal propionate production (Armentano and Young, 1983). It has been observed that cows fed higher-energy diets postpartum (Andersen et al., 2002, 2004; Rabelo et al., 2005) and monensin during the peripartal period 
(Arieli et al., 2008; Duffield et al., 2008a) have improvements in postpartum energy metabolism.

The hepatic oxidation theory proposed by Allen et al. (2009) would suggest that feeding diets that promote greater ruminal propionate production (e.g., high in fermentable starch, monensin supplementation) during early lactation would be hypophagic and further exacerbate the state of negative EB due to the increased oxidation of propionate in the liver. However, it has been observed that cows fed more propiogenic diets have increased DMI in early lactation (Andersen et al., 2003; Rabelo et al., 2003; McCarthy et al., 2015). The hypophagic effect of propionate is likely to be reduced in the immediate postpartum period because of the large increase in hepatic energy demands at the onset of lactation (Reynolds et al., 2003). The increase in early-lactation NEFA mobilization (Vernon, 2005) and subsequent hepatic uptake of NEFA and mitochondrial $\beta$-oxidation of fatty acyl CoA to acetyl CoA provide substantial amounts of oxidative substrate, in addition to propionate, to the tricarboxylic acid cycle (Drackley et al., 2001).

When there is an increase in propionate supply to the liver, early-lactation cows appear to have an increased propensity to convert the propionate to glucose rather than oxidize it (Drackley et al., 2001). The rate of gluconeogenesis from $\left[1-{ }^{14} \mathrm{C}\right]$ propionate in liver slices from early-lactation cows are increased compared with the rate in liver slices from the same cows once they have reached mid-lactation (Aiello et al., 1989). Drackley et al. (2001) found a positive correlation between carbohydrate intake in the immediate postpartum period with the efficiency of $\left[1-{ }^{14} \mathrm{C}\right]$ propionate conversion to glucose in liver biopsy slices, which would suggest that the liver has the capacity to direct additional propionate toward glucose during early lactation.

Monensin has been shown to decrease the incidence of periparturient health disorders associated with negative EB and improve energy metabolism (Duffield et al., $2008 \mathrm{~b}, \mathrm{c})$. However, it is of interest to determine whether effects of monensin in fresh cows are independent of dietary starch content, as both will likely increase supply of propionate, leading to increased hepatic oxidative supply. The objectives of this study were to evaluate the effect of dietary starch content during the immediate postpartum period and monensin inclusion during the periparturient and early-lactation period on metabolic indices related to energy metabolism and in vitro hepatic gluconeogenesis. We hypothesized that increasing the starch content during the immediate postpartum period and feeding monensin throughout the periparturient period and into early lactation would increase hepatic gluconeogenesis as well as improve measures of energy metabolism.

\section{MATERIALS AND METHODS}

\section{Animals and Dietary Treatments}

All animal procedures were approved by the Cornell University Institutional Animal Care and Use Committee, and the experiment was conducted from March to October 2012. The experimental design and treatments were described more completely in the companion paper (McCarthy et al., 2015). Briefly, the study was a completely randomized design with randomization restricted to balance for expected calving date of primiparous and multiparous cows and previous lactation 305-d mature-equivalent milk production for multiparous cows. A $2 \times 2$ factorial arrangement of postpartum treatments was used, with early-lactation period feeding strategy [high starch (HS) vs. low starch $(\mathbf{L S})$ diet during the first $21 \mathrm{~d}$ postpartum] and monensin supplementation $[0 \mathrm{mg}$ of monensin/d $(\mathbf{C O N})$ or 450 mg of monensin/d (MON); monensin; Elanco Animal Health, Greenfield, IN] as the variables of interest. In addition, cows that received MON during the postpartum period were fed MON (400 mg/d) initiated on $1 \mathrm{~d}$ between d 21 and 28 before expected parturition (average treatment of $25 \mathrm{~d}$; minimum of $14 \mathrm{~d}$ on treatment before actual parturition was required for inclusion in the data set). The final data set included 70 cows (primiparous $\mathrm{n}=21$, multiparous $\mathrm{n}=49$ ). Lactating cows were dried off at least $45 \mathrm{~d}$ (average dry period length of $53 \mathrm{~d}$ ) before expected parturition and moved to the experimental tie-stall barn approximately $28 \mathrm{~d}$ before expected parturition, where they began consuming the experimental close up dry cow diet.

Diet ingredients are presented in Table 1 and nutrient composition is shown in Table 2. Procedures and methods for feed sampling and analysis are detailed in McCarthy et al. (2015). The topdress pellets were formulated to contain either $0(\mathrm{CON})$ or $461 \mathrm{~g} / \mathrm{t}$ monensin $(\mathrm{MON})$ and were fed as a daily topdress at rates of 0.85 $\mathrm{kg} / \mathrm{d}$ prepartum and $0.95 \mathrm{~kg} / \mathrm{d}$ postpartum. The MON topdress was targeted to provide $400 \mathrm{mg} / \mathrm{d}$ prepartum and $450 \mathrm{mg} / \mathrm{d}$ postpartum. Cows continued to receive assigned topdress treatments through d 63 postpartum.

\section{Plasma and Tissue Sampling and Analyses}

Blood samples were collected via venipuncture of the coccygeal vessels using heparinized Vacutainer (Becton Dickinson, Franklin Lakes, NJ) tubes $1 \mathrm{~h}$ before feeding. Blood samples were collected $1 \times /$ wk prepartum beginning the week before commencement of prepartum topdress treatments, $3 \times /$ wk from calving through $21 \mathrm{~d}$ postpartum, and $1 \times /$ wk from d 22 to 63 . Blood samples were placed on ice immediately following col- 
Table 1. Ingredient composition of the basal diets (\% of DM)

\begin{tabular}{|c|c|c|c|}
\hline \multirow[b]{2}{*}{ Item } & \multirow[b]{2}{*}{ Prepartum } & \multicolumn{2}{|c|}{ Postpartum $^{1}$} \\
\hline & & HS & $\mathrm{LS}$ \\
\hline Corn silage, processed & 42.14 & - & - \\
\hline BMR corn silage $^{2}$ & & 38.50 & 38.50 \\
\hline Wheat straw & 21.75 & 11.54 & 11.55 \\
\hline Legume silage & - & 9.62 & 9.62 \\
\hline Shelled corn, finely ground & 4.28 & 20.97 & 10.29 \\
\hline Citrus pulp & 7.23 & 1.01 & 7.15 \\
\hline Corn germ meal & - & 2.52 & 5.56 \\
\hline Soybean hulls & 7.08 & - & 3.58 \\
\hline Soybean meal & 5.27 & 5.87 & 3.86 \\
\hline Canola meal & 4.63 & 2.73 & 2.08 \\
\hline Blood meal & 1.05 & 1.94 & 1.93 \\
\hline Amino Plus ${ }^{3}$ & 1.78 & 1.70 & 2.34 \\
\hline Energy Booster $100^{4}$ & - & 0.77 & 0.96 \\
\hline Calcium carbonate & 1.53 & 1.12 & 0.82 \\
\hline Sodium bicarbonate & - & 0.86 & 0.85 \\
\hline Soy Chlor ${ }^{5}$ & 1.33 & - & - \\
\hline Salt & 0.16 & 0.42 & 0.41 \\
\hline Calcium sulfate & 0.73 & 0.17 & 0.17 \\
\hline Magnesium oxide & 0.20 & 0.15 & 0.15 \\
\hline Magnesium sulfate, $9.9 \%$ & 0.61 & - & - \\
\hline Selenium $0.06 \%$ & 0.04 & 0.05 & 0.05 \\
\hline Mono dicalcium phosphate & - & 0.02 & 0.07 \\
\hline Trace mineral premix ${ }^{6}$ & 0.02 & 0.03 & 0.03 \\
\hline Vitamin A, D, E premix ${ }^{7}$ & 0.05 & 0.02 & 0.02 \\
\hline Vitamin E premix ${ }^{8}$ & 0.005 & - & - \\
\hline Zinc sulfate & 0.002 & - & - \\
\hline Copper sulfate & 0.0004 & 0.001 & 0.001 \\
\hline
\end{tabular}

${ }^{1} \mathrm{HS}=$ high-starch $\operatorname{diet}(26.2 \%$ starch $) ; \mathrm{LS}=$ low-starch $\operatorname{diet}(21.5 \%$ starch).

${ }^{2} \mathrm{BMR}=$ brown midrib corn silage.

${ }^{3}$ AGP Inc., Omaha, NE.

${ }^{4}$ Milk Specialties Global, Carpentersville, IL.

${ }^{5}$ West Central, Ralston, IA.

${ }^{6}$ Contained $30,317 \mathrm{mg} / \mathrm{kg}$ of $\mathrm{Cu}, 136,466 \mathrm{mg} / \mathrm{kg}$ of $\mathrm{Mn}, 3,393 \mathrm{mg} / \mathrm{kg}$ of $\mathrm{Co}, 3,040 \mathrm{mg} / \mathrm{kg}$ of I, and $153,916 \mathrm{mg} / \mathrm{kg}$ of $\mathrm{Zn}$.

${ }^{7}$ Contained $30,464 \mathrm{IU} / \mathrm{kg}$ of vitamin A, 5,862 IU $/ \mathrm{kg}$ of vitamin D, and $93,784 \mathrm{IU} / \mathrm{kg}$ of vitamin $\mathrm{E}$.

${ }^{8}$ Contained $510,750 \mathrm{IU} / \mathrm{kg}$ of vitamin E.

lection, and plasma was harvested after centrifugation of the blood at $1,300 \times g$ for $15 \mathrm{~min}$ at $4^{\circ} \mathrm{C}$. Plasma was stored at $-20^{\circ} \mathrm{C}$ until subsequent analysis for glucose, NEFA, BHBA, haptoglobin, and insulin. Plasma concentrations of glucose were determined by enzymatic analysis (glucose oxidase; protocol from kit 510-A; Sigma-Aldrich, St. Louis, MO) using commercial products (PGO Enzyme Preparation and o-dianisidine dihydrochloride, Sigma-Aldrich). Plasma concentrations of NEFA were also analyzed by enzymatic analysis [HR Series NEFA HR (2), Wako Pure Chemical Industries, Osaka, Japan]. Plasma concentrations of BHBA were analyzed by enzymatic analysis (BHBA dehydrogenase) using commercial products [nicotinamide adenine dinucleotide and Tris (hydroymethyl)aminomethane, Sigma-Aldrich; 3-hydroxybutyrate dehydrogenase, Roche Diagnostics Co., Indianapolis, IN]. Plasma con- centrations of haptoglobin were only determined on $\mathrm{d}$ 1 to 15 plasma samples, and were analyzed by enzymatic analysis using a commercial kit that measures haptoglobin-hemoglobin complex by estimated differences in peroxidase activity (Haptoglobin Assay, kit no. TP801, Tridelta Diagnostics Ltd., Morris Plains, NJ). All spectrophotometric measurements were conducted using a Versamax tunable microplate reader (Molecular Devices, Sunnyvale, CA). Inter- and intraassay variation was maintained at $<10 \%$ for all enzymatic assays. Plasma concentrations of insulin were determined by double-antibody RIA (Porcine Insulin RIA cat. no. PI-12K, Linco Research/Millipore, St. Charles, MO), with a reported specificity to bovine insulin of $90 \%$. Inter- and intraassay coefficients of variation were 13.3 and $13.5 \%$, respectively.

The revised quantitative insulin sensitivity check index (RQUICKI), a relative insulin sensitivity measure used in ruminants, was calculated as follows (Holtenius and Holtenius, 2007):

$$
\begin{gathered}
\text { RQUICKI }=1 /[\log (\text { glucose }, \mathrm{mg} / \mathrm{dL}) \\
+\log (\text { insulin, } \mu \mathrm{U} / \mathrm{mL})+\log (\mathrm{NEFA}, \mathrm{mmol} / \mathrm{L})]
\end{gathered}
$$

such that a lower RQUICKI suggests greater insulin resistance.

\section{Liver Biopsy, Liver Metabolic Incubations, and Liver Composition}

Liver tissue (3-5 g) was sampled via percutaneous trocar biopsy (Veenhuizen et al., 1991) from cows under local anesthesia on $\mathrm{d} 7$ ( $\pm 4 \mathrm{~d}$ range; $\pm 1.6 \mathrm{SD})$ relative to parturition. Biopsies were obtained from at least 7 multiparous cows and 4 primiparous cows from each treatment. After blotting the liver sample to remove excess blood and connective tissue, a portion of the sample was immersed in ice-cold PBS $(0.015$ M; $0.9 \%$ $\mathrm{NaCl}, \mathrm{pH}$ 7.4) and transported to the laboratory within $45 \mathrm{~min}$ of tissue collection. The remaining portion of liver tissue that was collected was snap-frozen in liquid $\mathrm{N}$ and stored at $-80^{\circ} \mathrm{C}$ until analysis for triglyceride and glycogen contents. Liver triglyceride content was determined using the Folch extraction method (Folch et al., 1957) followed by a colorimetric method based upon the Hantzsch condensation for estimating serum triglyceride (Fletcher, 1968) with modifications described by Foster and Dunn (1973). Glycogen content of liver was determined according to the procedures described by Bernal-Santos et al. (2003).

Hepatic capacities for conversion of $\left[1-{ }^{14} \mathrm{C}\right]$ propionate ( $1 \mu \mathrm{Ci}$ per flask; American Radiolabeled Chemicals Inc., St. Louis, MO) in Krebs-Ringer bicarbonate medium 
Table 2. Chemical composition of experimental diets $\left( \pm \mathrm{SD}^{1}\right)$

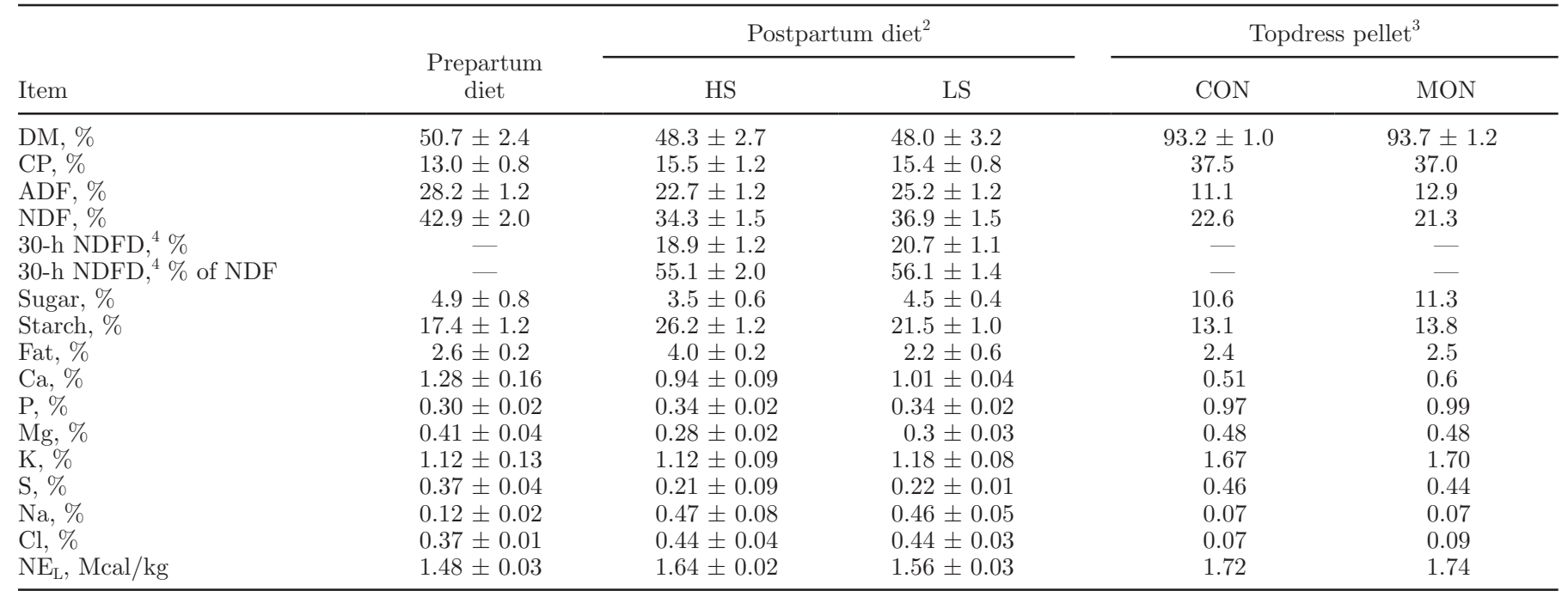

${ }^{1}$ Chemcial composition was analyzed on 6 composite samples of the prepartum diet, 7 composite samples of the high-starch postpartum diet, and 6 composite samples of the low-starch postpartum diet.

${ }^{2} \mathrm{HS}=$ high-starch diet $(26.2 \%$ starch $)$ and LS $=$ low-starch diet $(21.5 \%$ starch $)$.

${ }^{3}$ The composition of the topdress was $33.6 \%$ soybean meal, $33.2 \%$ wheat middlings, and $33.2 \%$ canola meal (DM basis). CON $=$ control topdress, formulated to supplement $0 \mathrm{mg} / \mathrm{d}$ monensin; MON $=$ monensin topdress, formulated to supplement $400 \mathrm{mg} / \mathrm{d} \mathrm{prepartum}$ and $450 \mathrm{mg} / \mathrm{d}$ postpartum.

${ }^{4} \mathrm{NDFD}=\mathrm{NDF}$ digestibility.

(final substrate concentration of $10 \mathrm{mM}$ ) to $\mathrm{CO}_{2}$ and glucose were measured in triplicate flasks using tissue slices (60 to $80 \mathrm{mg}$ ) according to procedures described by Piepenbrink et al. (2004). Tissue metabolism was terminated using $0.5 \mathrm{~mL}$ of $0.75 \mathrm{M} \mathrm{H}_{2} \mathrm{SO}_{4}$ injected into the medium at either 0 (blanks) or 120 min of incubation. After termination of tissue metabolism, evolved $\mathrm{CO}_{2}$ was collected on $\mathrm{NaOH}$-soaked $(0.1 \mathrm{~mL} ; 30 \%$ wt/ vol) filter paper in a hanging center well for $1 \mathrm{~h}$ in a shaking ice-water bath. After $1 \mathrm{~h}$, flasks were uncapped and the filter paper was removed to a scintillation vial and dried overnight under moving air at $39^{\circ} \mathrm{C}$. Ten milliliters of scintillation cocktail (Scintisafe Econo 2; Fisher Scientific, Pittsburgh, PA) was added to each vial and radioactivity was measured using liquid scintillation spectroscopy (2200 CA Tricarb Liquid Scintillation Analyzer, Packard Instrument Co., Meriden, CT).

After uncapping the flasks and removing the hanging center well for measurement of $\mathrm{CO}_{2}$, the contents of each flask were processed for gluconeogenesis. An internal standard $\left(\left[{ }^{3} \mathrm{H}\right]\right.$ L-glucose, $0.055 \mu \mathrm{Ci}$ per flask; American Radiolabeled Chemicals Inc.) was added to the medium, and flasks were neutralized and deproteinized by additions of saturated $\mathrm{Ba}(\mathrm{OH})_{2}$ solution. Radioactive glucose from media supernatants was isolated using an ion-exchange method of Azain and Kasser (1999) as modified by Piepenbrink et al. (2004). Radioactivity was measured using dual-label liquid scintillation spectroscopy.

\section{Statistical Analyses}

Statistical computations were performed using SAS software (version 9.2; SAS Institute Inc., Cary, NC). Data were analyzed separately as wk -4 to -1 prepartum, d 1 to 21 (dietary treatment period), and wk 1 to 9 postpartum (duration of experiment). The $3 \times /$ wk sampling schedule from d 1 to 21 postpartum resulted in cows being sampled on different days relative to calving, thus 3-d average day intervals were calculated for these analyses. For weeks with multiple blood samples/week (wk 1 to 3), data were averaged to weekly means before wk 1 to 9 analyses. The prepartum model include the fixed effects MON treatment, parity, and the 2-way interactions. The random effect was cow nested within MON treatment. Postpartum data were analyzed as a completely randomized design with a $2 \times 2$ factorial arrangement of treatments. Fixed effects included starch content, MON treatment, parity, time, and all 2-way interactions. A prepartum covariate (week before starting topdress treatment) was used for all plasma glucose, NEFA, BHBA, insulin, and RQUICKI analyses. The random effect was cow nested within starch and MON treatment. Data measured over time were subjected to ANOVA using the REPEATED statement in the MIXED procedure of SAS (Littell et al., 1996). For variables with measurements repeated over time, 4 covariance structures were tested: compound symmetry, heterogeneous compound symmetry, 
first-order autoregressive, and heterogeneous first-order autoregressive; the covariance structure that resulted in the smallest Akaike's information criterion was used (Littell et al., 1996). Data not analyzed over time were subjected to ANOVA using the MIXED procedure of SAS (Littell et al., 1996). Fixed effects included starch content, MON treatment, parity, and all 2-way interactions. The random effect was cow nested within starch and MON treatment. Degrees of freedom were estimated by using the Kenward-Roger option in the model statement. Statistical significance was declared at $P \leq$ 0.05 and trends were discussed at $0.05<P \leq 0.10$, with the exception of the in vitro liver metabolism. Because a subset of cows was used for this analysis, trends were declared at $0.05<P \leq 0.15$.

Effects of parity, starch, and MON on occurrence of subclinical ketosis and health outcomes were analyzed by $\chi^{2}$ test for each effect using the FREQ procedure of SAS (SAS Institute Inc., Cary, NC), with statistical significance declared at $P \leq 0.05$ and trends discussed at $0.05<P \leq 0.15$.

\section{RESULTS}

\section{Prepartum Plasma Metabolites}

The MON treatment had no effect on prepartum plasma metabolite concentrations for glucose, NEFA, BHBA, insulin, or RQUICKI (Table 3).

\section{Postpartum Plasma Metabolites}

Postpartum plasma metabolite results are presented in Table 4. Cows fed HS had higher plasma glucose concentrations than cows fed LS during $d 1$ to 21 postpartum $(P=0.003)$ and tended to have higher glucose during wk 1 to $9(P=0.06)$. We detected a starch $\times$ week interaction (Figure 1A; $P=0.007$ ) during wk 1 to 9 , such that cows that were fed HS had higher early-lactation plasma glucose concentrations com- pared with cows fed LS; however, LS cows maintained similar plasma glucose concentrations as HS cows after all cows were switched to the HS diet beginning on d 22 postpartum. Cows fed HS had lower plasma NEFA concentrations during both d 1 to $21(P=0.002)$ and wk 1 to $9(P=0.002)$ postpartum than cows fed LS. We detected an interaction of starch $\times$ week for wk 1 to 9 (Figure 2A; $P=0.01$ ) such that cows fed HS had lower plasma NEFA concentrations during wk 1, 2 , and 3 compared with cows fed LS; however, there was no difference between treatments in plasma NEFA concentrations after cows fed LS started consuming the HS diet on d 22 postpartum. We detected a starch $x$ parity interaction $(P=0.04)$ for wk 1 to 9 data, and primiparous cows fed LS had higher plasma NEFA than primiparous cows fed HS (503.3 vs. $361.3 \mu \mathrm{Eq} / \mathrm{L})$, but plasma NEFA concentrations in multiparous cows were similar between the 2 diets (average $393.6 \mu \mathrm{Eq} / \mathrm{L}$ ). During d 1 to 21, cows fed HS had lower plasma BHBA concentrations compared with cows fed LS $(P=0.03)$. We detected a starch $\times$ time interaction during both d 1 to $21(P=0.04)$ and wk 1 to 9 (Figure $3 \mathrm{~A} ; P=$ 0.02 ) because cows fed LS had elevated early-lactation BHBA concentrations compared with cows fed HS. Cows fed HS had greater insulin concentrations during both d 1 to $21(P=0.008)$ and wk 1 to $9(P=0.004$; Figure $4 \mathrm{~A})$. There was a tendency for a starch $\times$ parity interaction $(P=0.09)$ during wk 1 to 9 because primiparous cows fed HS tended to have larger increases in insulin concentrations than multiparous cows ( 0.32 vs. $0.21 \mathrm{ng} / \mathrm{mL}$ ), with less difference between primiparous and multiparous cows fed LS (0.24 vs. $0.19 \mathrm{ng} / \mathrm{mL}$ ). Cows fed HS had lower RQUICKI than cows fed LS during $\mathrm{d} 1$ to $21(P=0.002)$ and tended to have lower RQUICKI during wk 1 to 9 (Figure $5 \mathrm{~A} ; P=0.09$ ). However, there was a starch $\times$ MON interaction $(P=$ 0.02 ) for RQUICKI during $d 1$ to 21 such that cows fed HS and MON had a lower RQUICKI compared with cows fed HS without MON, and no differences for cows fed LS with or without MON. Cows fed HS had higher

Table 3. Prepartum plasma metabolites as affected by monensin supplementation beginning during the prepartum period

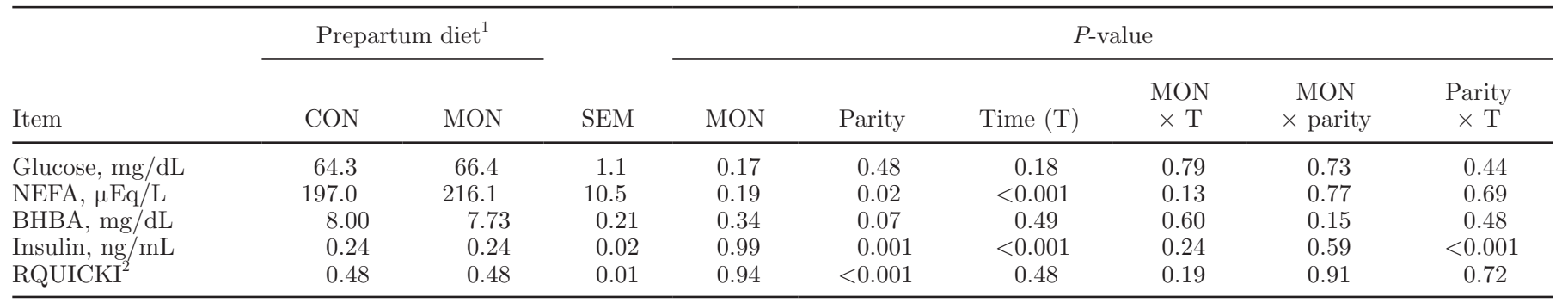

${ }^{1} \mathrm{CON}=$ control topdress (formulated to supplement $0 \mathrm{mg} / \mathrm{d}$ monensin); MON = monensin topdress (formulated to supplement $400 \mathrm{mg} / \mathrm{d}$ prepartum and $450 \mathrm{mg} / \mathrm{d}$ postpartum).

${ }^{2}$ Revised quantitative insulin sensitivity check index $($ RQUICKI $)=1 /[\log ($ glucose $)+\log ($ insulin $)+\log ($ NEFA $)]$. 
haptoglobin concentrations (Figure $6 \mathrm{~A} ; P=0.04$ ) during $\mathrm{d} 1$ to 15 postpartum compared with cows fed LS.

Cows fed MON during the transition period had higher plasma glucose concentrations than CON cows during both $\mathrm{d} 1$ to $21(P<0.001)$ and wk 1 to 9 (Figure $1 \mathrm{~B} ; P=0.005)$. There was a $\mathrm{MON} \times$ parity interaction $(P=0.008)$ during $\mathrm{d} 1$ to 21 such that primiparous cows fed MON had greater increases in plasma glucose concentration than did primiparous CON cows (62.0 vs. $54.2 \mathrm{mg} / \mathrm{dL}$ ), with less difference in plasma glucose concentrations for multiparous cows fed MON and CON (54.1 vs. $52.4 \mathrm{mg} / \mathrm{dL}$ ). Although we observed no effect of MON treatment on postpartum plasma NEFA (Figure 2B), cows fed MON during the transition period had lower plasma BHBA during d 1 to $21(P=$ 0.002 ) and tended to have lower plasma BHBA during wk 1 to 9 (Figure 3B; $P=0.06$ ) compared with $\mathrm{CON}$ cows. There was a MON $\times$ parity interaction $(P=0.03)$ during $\mathrm{d} 1$ to 21 such that primiparous cows fed MON had larger decreases in BHBA than did primiparous CON cows (10.11 vs. $13.99 \mathrm{mg} / \mathrm{dL}$ ) with less difference in plasma BHBA concentrations for multiparous cows fed MON and CON (10.04 vs. $11.33 \mathrm{mg} / \mathrm{dL})$. There was a $\mathrm{MON} \times$ day $(P=0.04)$ interaction for plasma insulin concentration during d 1 to 21 , although differences were inconsistent and variable across the period studied. Plasma insulin for wk 1 to 9 is shown in Figure $4 \mathrm{~B}$. Whereas there was no overall effect of MON treatment on postpartum plasma RQUICKI concentrations (Figure 5B), we did detect a tendency for an interaction of MON $\times$ parity $(P=0.09)$ during $\mathrm{d} 1$ to 21 for RQUICKI, although RQUICKI between MON and CON primiparous cows were similar (0.46 vs. 0.48 ), as was RQUICKI between MON and CON multiparous cows (0.52 vs. 0.51). There were no effects of MON treatment on postpartum plasma haptoglobin concentrations (Figure 6B).

\section{Subclinical Ketosis and Health Outcomes}

Subclinical ketosis results are presented in Table 5 . Feeding HS during early lactation tended to result in fewer cows with 2 or more consecutive days of plasma BHBA $\geq 12 \mathrm{mg} / \mathrm{dL}(P=0.15)$. The MON treatment resulted in a decreased percentage of cows with $\geq 1$ days with plasma BHBA concentrations $\geq 12 \mathrm{mg} /$ $\mathrm{dL}(P=0.02)$ and with $\geq 2$ consecutive days with a plasma BHBA concentration $\geq 12 \mathrm{mg} / \mathrm{dL}(P=0.009)$ compared with CON cows.

The frequency of occurrence of various health disorders is reported in Table 6. However, because of the small population of cows studied, care should be taken in extrapolating these results. Health event occurrences did not differ greatly among dietary treatments; how- ever, cows fed HS tended to have fewer cases of clinical ketosis $(P=0.15)$. Cows on the MON treatment had fewer cases of clinical ketosis $(P=0.03)$ and tended to have a greater incidence of retained placenta and dystocia $(P=0.10$ for both) compared with cows receiving the CON topdress; however, there were only 3 cases each of retained placenta and dystocia. The 3 cases of dystocia occurred in primiparous cows $(P=0.02$; parity effect).

\section{Liver Composition}

Results for postpartum liver composition are shown in Table 7 . We detected no effect of starch treatment on liver triglyceride content in biopsies taken on $\mathrm{d} 7$ $( \pm 1.6 \mathrm{SD})$ postpartum. There was a $\mathrm{MON} \times$ parity interaction $(P=0.05)$ such that primiparous cows fed MON during the transition period had increased liver triglyceride content compared with CON primiparous cows (6.1 vs. $3.7 \%$ of wet wt.), whereas multiparous cows fed MON had decreased liver triglyceride content compared with multiparous CON cows (6.1 vs. $9.4 \%$ of wet wt.). For liver glycogen, we detected a starch $\times$ MON interaction $(P=0.008)$, and cows fed LS with MON had higher liver glycogen content than cows fed LS without MON, with no effect of MON treatment for cows fed HS.

\section{In Vitro Liver Metabolism}

Results for in vitro liver metabolism are presented in Table 8. Cows fed MON tended $(P=0.14)$ to have greater capacity to convert $\left[1-{ }^{14} \mathrm{C}\right]$ propionate to glucose than $\mathrm{CON}$ cows. Cows fed MON had an increased ratio of glucose to $\mathrm{CO}_{2}(P=0.05)$, indicating that cows fed MON had a greater propensity to convert propionate to glucose. There were no effect of starch or MON treatment on liver capacity to oxidize $\left[1-{ }^{14} \mathrm{C}\right]$ propionate to $\mathrm{CO}_{2}$, and the effects of starch on liver capacity to convert propionate to glucose and on the ratio of glucose to $\mathrm{CO}_{2}$ were not significant. Primiparous cows had greater capacity to both oxidize $\left[1-{ }^{14} \mathrm{C}\right]$ propionate to $\mathrm{CO}_{2}$ and convert $\left[1-{ }^{14} \mathrm{C}\right]$ propionate to glucose than did multiparous cows $(P=0.04$ and 0.01 , respectively).

\section{DISCUSSION}

We hypothesized that increasing starch content during the immediate postpartum period and feeding monensin throughout the periparturient period would increase hepatic gluconeogenesis and improve energy metabolism by increasing the amount of ruminal propionate available to the liver. During the weeks immediately following parturition, the increased glucose 
Table 4. Postpartum plasma metabolites for cows fed high- or low-starch diets during the first 3 wk postpartum and control or monensin treatments throughout the periparturient period and into early lactation

\begin{tabular}{|c|c|c|c|c|c|c|c|c|c|c|c|c|c|c|}
\hline \multirow[b]{2}{*}{ Item } & \multicolumn{2}{|c|}{ Diet $^{1}$} & \multirow[b]{2}{*}{ SEM } & \multicolumn{2}{|c|}{ Topdress ${ }^{2}$} & \multirow[b]{2}{*}{ SEM } & \multicolumn{8}{|c|}{$P$-value ${ }^{3}$} \\
\hline & HS & LS & & $\mathrm{CON}$ & MON & & S & M & $\mathrm{P}$ & $\mathrm{S} \times \mathrm{M}$ & $\mathrm{S} \times \mathrm{T}$ & $\mathrm{M} \times \mathrm{T}$ & $\mathrm{S} \times \mathrm{P}$ & $\mathrm{M} \times \mathrm{P}$ \\
\hline \multicolumn{15}{|l|}{ Glucose, $\mathrm{mg} / \mathrm{dL}$} \\
\hline d 1 to 21 & 57.5 & 53.9 & 0.85 & 53.3 & 58.1 & 1.0 & 0.003 & $<0.001$ & $<0.001$ & 0.34 & 0.19 & 0.76 & 0.31 & 0.008 \\
\hline wk 1 to 9 & 59.3 & 57.0 & 0.9 & 56.4 & 59.9 & 0.9 & 0.06 & 0.005 & 0.01 & 0.32 & 0.007 & 0.48 & 0.73 & 0.18 \\
\hline \multicolumn{15}{|l|}{ NEFA, $\mu \mathrm{Eq} / \mathrm{L}$} \\
\hline d 1 to 21 & 533.1 & 696.6 & 35.9 & 643.9 & 585.8 & 35.4 & 0.002 & 0.25 & 0.42 & 0.23 & 0.13 & 0.29 & 0.37 & 0.43 \\
\hline wk 1 to 9 & 386.0 & 456.9 & 19.8 & 412.6 & 413.2 & 19.6 & 0.002 & 0.98 & 0.20 & 0.34 & 0.01 & 0.21 & 0.04 & 0.45 \\
\hline \multicolumn{15}{|l|}{ BHBA, mg/dL } \\
\hline d 1 to 21 & 10.51 & 12.22 & 0.57 & 12.66 & 10.08 & 0.58 & 0.03 & 0.002 & 0.10 & 0.35 & 0.04 & 0.41 & 0.56 & 0.03 \\
\hline wk 1 to 9 & 9.20 & 9.78 & 0.40 & 10.02 & 8.80 & 0.48 & 0.29 & 0.06 & 0.02 & 0.24 & 0.02 & 0.15 & 0.92 & 0.16 \\
\hline \multicolumn{15}{|l|}{ Insulin, $\mathrm{ng} / \mathrm{mL}$} \\
\hline d 1 to 21 & 0.26 & 0.19 & 0.02 & 0.22 & 0.23 & 0.02 & 0.008 & 0.88 & $<0.001$ & 0.43 & 0.20 & 0.04 & 0.17 & 0.33 \\
\hline wk 1 to 9 & 0.27 & 0.21 & 0.01 & 0.24 & 0.24 & 0.01 & 0.004 & 0.97 & $<0.001$ & 0.14 & 0.14 & 0.12 & 0.09 & 0.13 \\
\hline \multicolumn{15}{|l|}{ RQUICKI $^{4}$} \\
\hline d 1 to 21 & 0.48 & 0.51 & 0.01 & 0.49 & 0.49 & 0.01 & 0.002 & 0.69 & $<0.001$ & 0.02 & 0.95 & 0.21 & 0.29 & 0.10 \\
\hline wk 1 to 9 & 0.51 & 0.53 & 0.01 & 0.53 & 0.51 & 0.01 & 0.09 & 0.29 & 0.003 & 0.11 & 0.92 & 0.38 & 0.74 & 0.03 \\
\hline \multicolumn{15}{|l|}{ Haptoglobin, g/L } \\
\hline d 1 to 15 & 1.03 & 0.77 & 0.09 & 0.93 & 0.88 & 0.11 & 0.04 & 0.70 & 0.66 & 0.27 & 0.48 & 0.37 & 0.41 & 0.56 \\
\hline
\end{tabular}

${ }^{1}$ Postpartum diets: HS = high-starch diet (26.2\% starch); LS = low-starch diet (21.5\% starch).

¿ $\quad{ }^{2} \mathrm{CON}=$ control topdress (formulated to supplement $0 \mathrm{mg} / \mathrm{d}$ monensin); MON = monensin topdress (formulated to supplement $400 \mathrm{mg} / \mathrm{d}$ prepartum and $450 \mathrm{mg} / \mathrm{d}$ postpartum).

${ }^{3} \mathrm{~S}=$ starch, $\mathrm{M}=$ monensin, $\mathrm{P}=$ parity, and $\mathrm{T}=$ time.

을 $\quad{ }^{4}$ Revised quantitative insulin sensitivity check index (RQUICKI) $=1 /[\log ($ glucose $)+\log ($ insulin $)+\log ($ NEFA $)]$. 
A

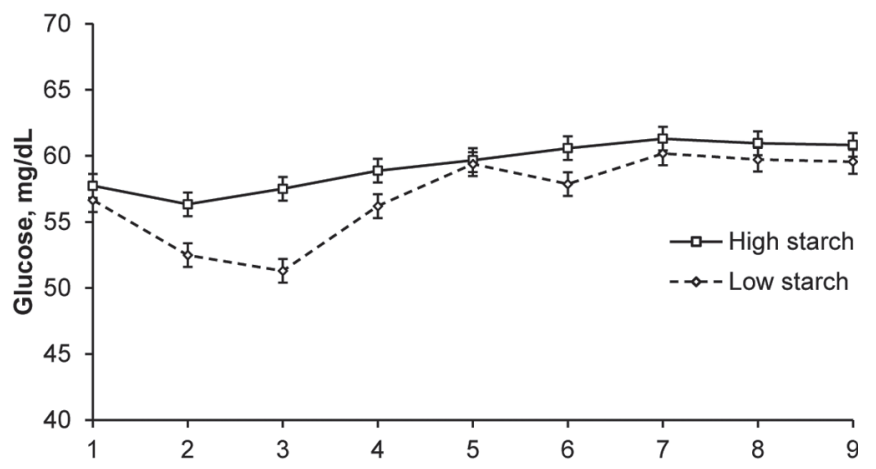

B

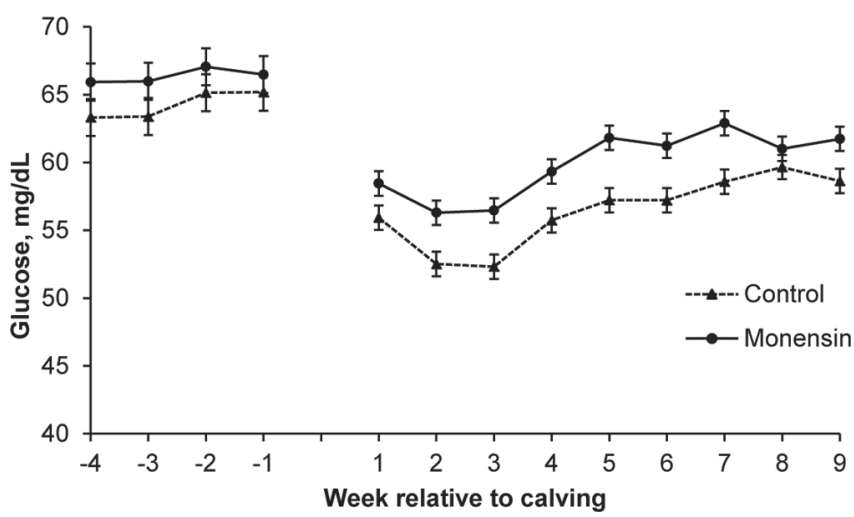

Figure 1. Least squares means $( \pm$ SEM $)$ for plasma glucose $(\mu \mathrm{Eq} / \mathrm{L})$ for cows fed different starch contents in the postpartum diet and monensin throughout the periparturient period. Postpartum data were analyzed separately as d 1 to 21 (dietary treatment period) and wk 1 to 9 (duration of experiment). (A) Effects of high (26.2\%) versus low $(21.5 \%)$ starch fed during wk 1 to 9 . Overall effects of starch content: $P=0.003$ during d 1 to 21 and $P=0.06$ during wk 1 to 9 ; interaction of starch content $\times$ time: $P=0.19$ for $\mathrm{d} 1$ to 21 and $P=$ 0.007 for wk 1 to 9. (B) Effects of monensin supplementation (0 vs. $400 \mathrm{mg} / \mathrm{d}$ prepartum and $450 \mathrm{mg} / \mathrm{d}$ postpartum). Overall effect of monensin: $P=0.17$ prepartum, $P<0.001$ for $\mathrm{d} 1$ to 21 , and $P=0.005$ for wk 1 to 9 ; interaction of monensin $\times$ time: $P=0.79$ prepartum, $P$ $=0.76$ for $\mathrm{d} 1$ to 21 , and $P=0.48$ for wk 1 to 9 .

demands for milk production require homeorhetic adaptations to support both the increased energy demands of the mammary gland and peripheral tissue metabolism (Bauman and Currie, 1980). In the current study, cows fed HS maintained greater plasma glucose concentrations during early lactation than cows fed the LS diet. In the study of Andersen et al. (2003), cows fed a higher-energy propiogenic diet (26.7\% starch) had higher plasma glucose concentrations in early lactation compared with cows fed a low-energy diet $(17.8 \%$ starch). Similarly, Rabelo et al. (2003) observed that cows fed a higher-energy propiogenic postpartum diet $(47.2 \% \mathrm{NFC})$ had increased plasma glucose concentrations compared with cows fed a lower-energy diet postpartum (41.1\% NFC). In the current study, because the
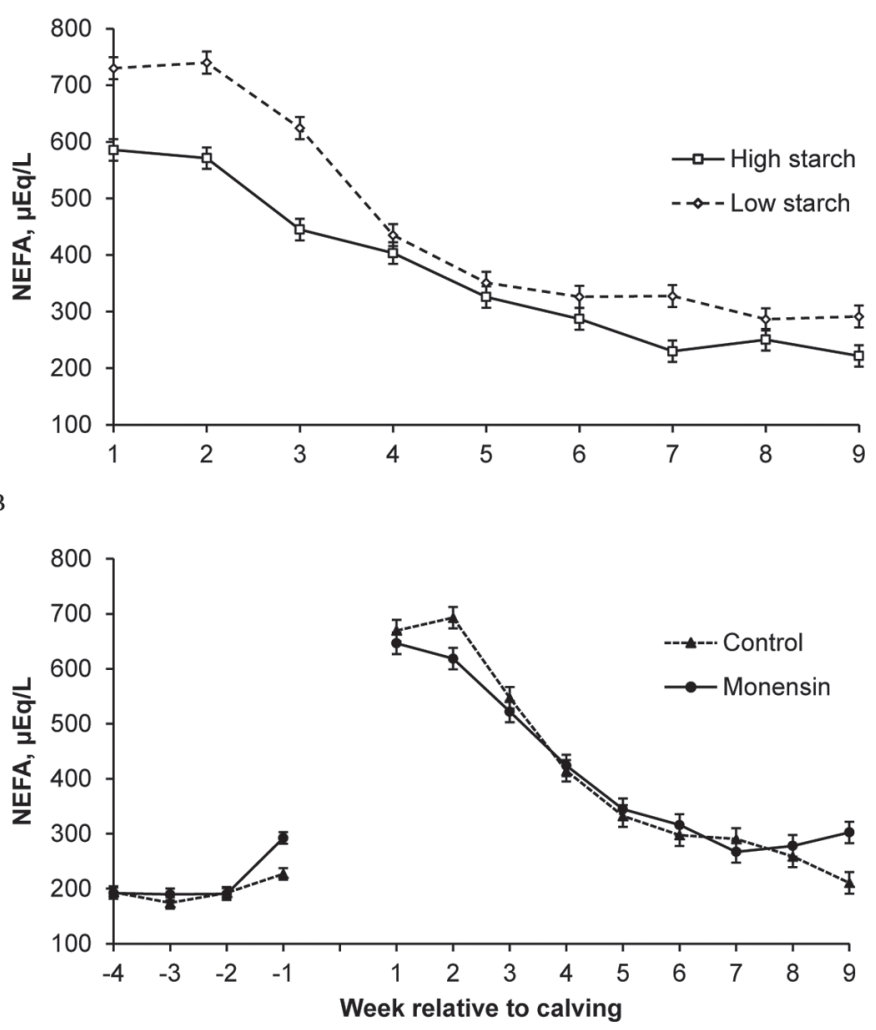

Figure 2. Least squares means ( \pm SEM) for plasma NEFA (mg/ dL) for cows fed different starch content in the postpartum diet and monensin throughout the periparturient period. Postpartum data were analyzed separately as d 1 to 21 (dietary treatment period) and wk 1 to 9 (duration of experiment). (A) Effects of high (26.2\%) versus low (21.5\%) starch fed during wk 1 to 9 . Overall effects of starch content: $P=0.002$ during d 1 to 21 and $P=0.002$ during wh 1 to 9 ; interaction of starch content $\times$ time: $P=0.13$ for $\mathrm{d} 1$ to 21 and $P=0.01$ for wk 1 to 9 . (B) Effects of monensin supplementation $(0$ vs. $400 \mathrm{mg} / \mathrm{d}$ prepartum and $450 \mathrm{mg} / \mathrm{d}$ postpartum). Overall effect of monensin: $P$ $=0.19$ prepartum, $P=0.25$ for $\mathrm{d} 1$ to 21 , and $P=0.98$ for wk 1 to 9 ; interaction of monensin $\times$ time: $P=0.13$ prepartum, $P=0.29$ for $\mathrm{d} 1$ to 21 , and $P=0.21$ for wk 1 to 9 .

cows fed MON continued with their topdress treatment for the duration of the study, they maintained higher plasma glucose compared with CON cows for the duration of the study, likely a result of increased propionate supply available to the liver. In the meta-analysis of Duffield et al. (2008b), monensin treatment resulted in a $3.2 \%$ increase in plasma glucose concentration, and Arieli et al. (2008) similarly observed that cows treated with monensin had increased plasma glucose in the early postpartum period. Together, these data suggest that feeding more propiogenic diets (with increased starch content or monensin inclusion) increases plasma glucose concentrations.

One homeorhetic adaptation that is used to help meet the postpartum energy demand is increased lipolysis of adipose tissue and mobilization of NEFA 
A

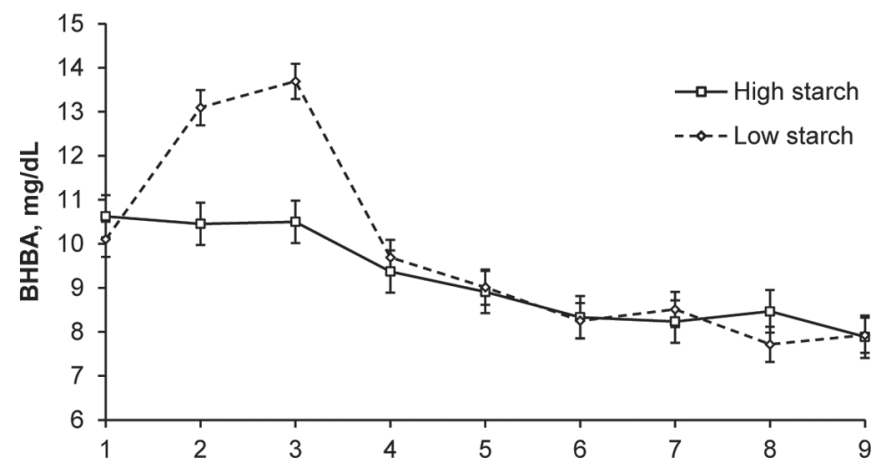

B

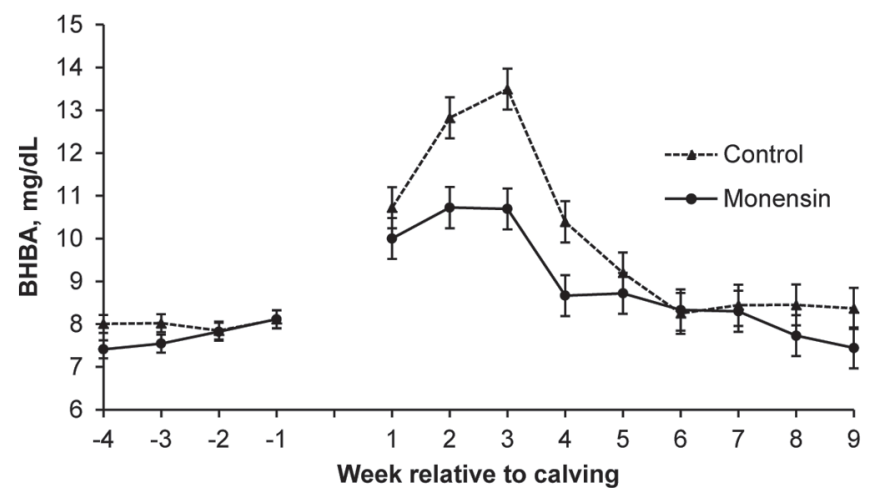

Figure 3. Least squares means ( \pm SEM) for plasma BHBA (mg/ $\mathrm{dL}$ ) for cows fed different starch content in the postpartum diet and monensin throughout the periparturient period. Postpartum data were analyzed separately as d 1 to 21 (dietary treatment period) and wk 1 to 9 (duration of experiment). (A) Effects of high (26.2\%) versus low (21.5\%) starch fed during wk 1 to 9. Overall effects of starch content: $P=0.03$ during d 1 to 21 and $P=0.29$ during wh 1 to 9 ; interaction of starch content $\times$ time: $P=0.04$ for $\mathrm{d} 1$ to 21 and $P=0.02$ for wk 1 to 9. (B) Effects of monensin supplementation (0 vs. $400 \mathrm{mg} / \mathrm{d}$ prepartum and $450 \mathrm{mg} / \mathrm{d}$ postpartum). Overall effect of monensin: $P$ $=0.34$ prepartum, $P=0.002$ for $\mathrm{d} 1$ to 21 , and $P=0.06$ for wk 1 to 9; interaction of monensin $\times$ time: $P=0.60$ prepartum, $P=0.41$ for d 1 to 21 , and $P=0.15$ for wk 1 to 9 .

as an energy substrate (Vernon, 2005). The uptake of NEFA by the liver is proportional to the concentration in the bloodstream (Reynolds et al., 2003), and NEFA can be oxidized to generate reducing equivalents or ketone bodies, reesterified, and exported as triglycerides in very low density lipoproteins (VLDL), or they can accumulate within the liver as stored triglycerides.

Cows that consume less energy in early lactation will need to mobilize more NEFA to meet energetic needs. In the current study, cows that were fed HS in early lactation had higher early-lactation DMI, less negative EB (McCarthy et al., 2015), and lower plasma NEFA concentrations compared with cows fed LS. However, other studies have observed no effect of early-lactation dietary energy content on NEFA mobilization (An-
A

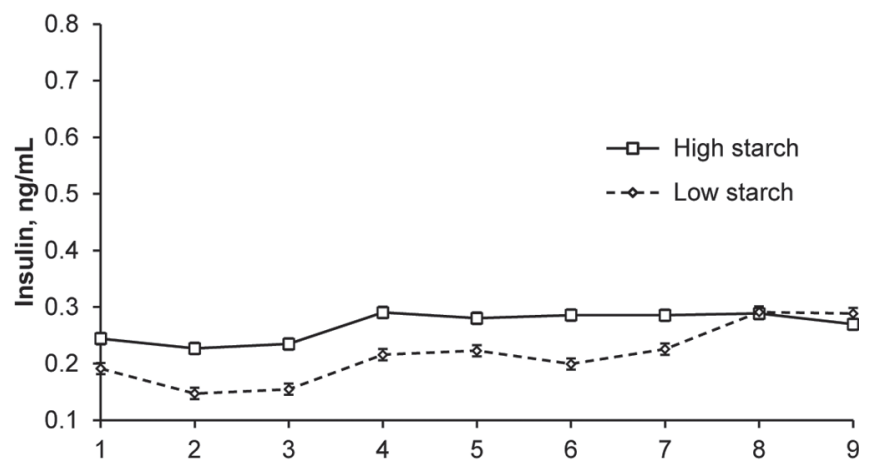

B

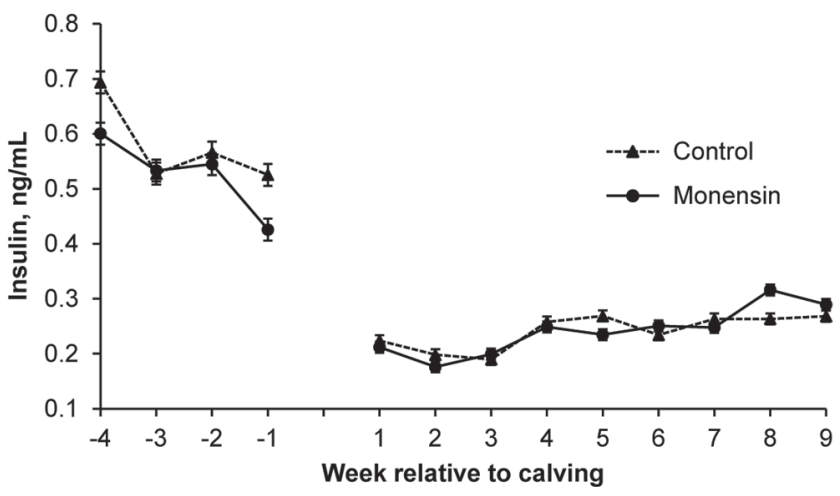

Figure 4. Least squares means ( \pm SEM) for plasma insulin (ng/ $\mathrm{mL}$ ) for cows fed different starch content in the postpartum diet and monensin throughout the periparturient period. Postpartum data were analyzed separately as d 1 to 21 (dietary treatment period) and wk 1 to 9 (duration of experiment). (A) Effects of high (26.2\%) versus low $(21.5 \%)$ starch fed during wk 1 to 9 . Overall effects of starch content: $P=0.008$ during $\mathrm{d} 1$ to 21 and $P=0.004$ during wk 1 to 9 ; interaction of starch content $\times$ time: $P=0.20$ for $\mathrm{d} 1$ to 21 and $P=0.14$ for wk 1 to 9 . (B) Effects of monensin supplementation (0 vs. $400 \mathrm{mg} / \mathrm{d}$ prepartum and $450 \mathrm{mg} / \mathrm{d}$ postpartum). Overall effect of monensin: $P$ $=0.99$ prepartum, $P=0.88$ for $\mathrm{d} 1$ to 21 , and $P=0.97$ for wk 1 to 9 ; interaction of monensin $\times$ time: $P=0.24$ prepartum, $P=0.04$ for $\mathrm{d} 1$ to 21 , and $P=0.12$ for wk 1 to 9 .

dersen et al., 2004; Rabelo et al., 2005). In the current study, the concurrent observations of increased plasma glucose and insulin concentrations for cows fed HS would indicate a decreased need for HS cows to mobilize adipose tissue compared with cows fed LS. Monensin treatment has also been shown to decrease circulating NEFA (Arieli et al., 2008; Duffield et al., 2008b), although, in the current study, we detected no effect of MON treatment on plasma NEFA concentration. We did observe that cows fed MON had lower BHBA, likely from increased DMI (McCarthy et al., 2015), increased gluconeogenic capacity, and decreased ketogenesis with MON treatment.

The partial oxidation of fatty acids to ketone bodies provides energetic substrate for the peripheral tissues, thereby sparing glucose for the mammary gland 
Table 5. Percentage of cows with elevated BHBA $(\geq 12 \mathrm{mg} / \mathrm{dL})$ during $\mathrm{d} 1$ to 21 as affected by dietary treatment

\begin{tabular}{|c|c|c|c|c|c|c|c|c|c|}
\hline Item & \multicolumn{2}{|c|}{$\operatorname{Diet}^{1}$} & \multicolumn{2}{|c|}{ Topdress ${ }^{2}$} & \multicolumn{2}{|c|}{ Parity } & \multicolumn{3}{|c|}{$P$-value ${ }^{3}$} \\
\hline $\begin{array}{l}\geq 1 \mathrm{~d} \text { of } \mathrm{BHBA} \geq 12 \mathrm{mg} / \mathrm{dL} \\
>2 \mathrm{~d} \text { of } B H B A>12 \mathrm{mg} / \mathrm{dL}\end{array}$ & $\begin{array}{l}63.9 \\
44.4\end{array}$ & $\begin{array}{l}67.7 \\
61.8\end{array}$ & $\begin{array}{l}78.4 \\
67.6\end{array}$ & $\begin{array}{l}51.5 \\
36.4\end{array}$ & $\begin{array}{l}66.7 \\
57.1\end{array}$ & $\begin{array}{l}65.3 \\
51.0\end{array}$ & $\begin{array}{l}0.74 \\
0.15\end{array}$ & $\begin{array}{l}0.02 \\
0.009\end{array}$ & $\begin{array}{l}0.91 \\
0.64\end{array}$ \\
\hline
\end{tabular}

${ }^{1}$ Postpartum diets: HS = high-starch diet (26.2\% starch); LS = low-starch diet (21.5\% starch).

${ }^{2} \mathrm{CON}=$ control topdress (formulated to supplement $0 \mathrm{mg} / \mathrm{d}$ monensin); $\mathrm{MON}=$ monensin topdress (formulated to supplement $400 \mathrm{mg} / \mathrm{d}$ prepartum and $450 \mathrm{mg} / \mathrm{d}$ postpartum).

${ }^{3} \mathrm{~S}=$ starch, $\mathrm{M}=$ monensin, and $\mathrm{P}=$ parity.

(Drackley et al., 2001). However, when an increased supply of propionate is available to the liver, ketone synthesis is decreased (Drackley et al., 2001). This

A

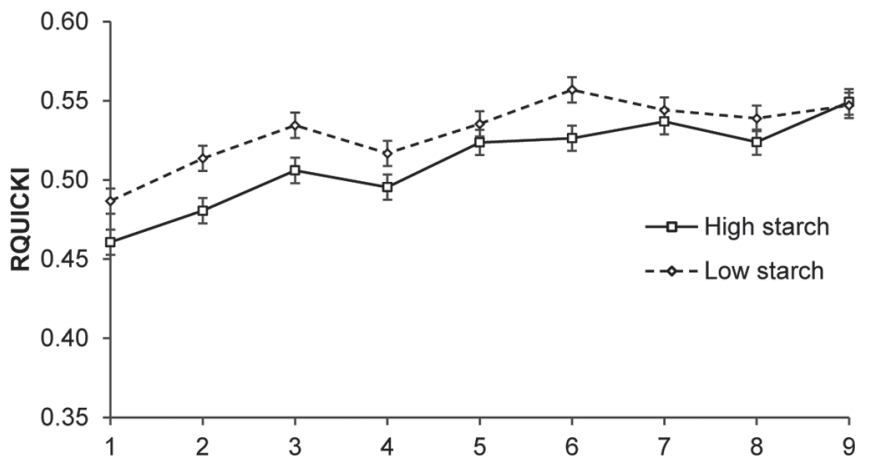

B

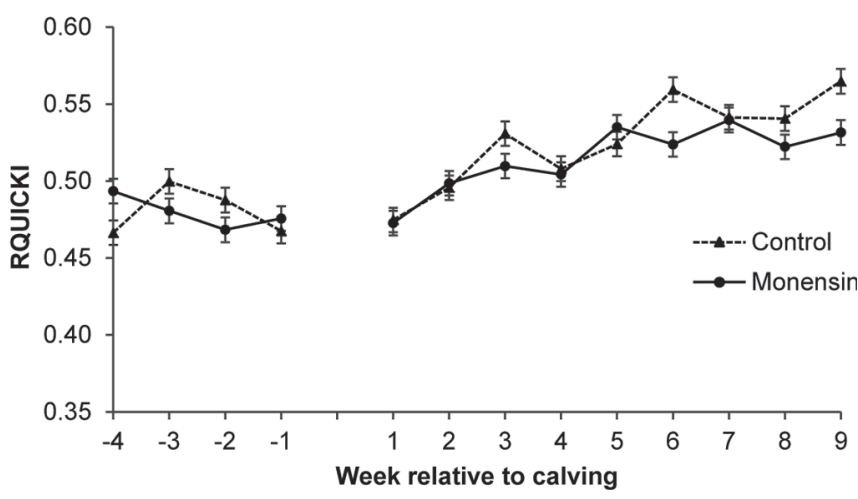

Figure 5. Least squares means $( \pm$ SEM) for revised quantitative insulin sensitivity check index (RQUICKI) for cows fed different starch content in the postpartum diet and monensin throughout the periparturient period. Postpartum data were analyzed separately as d 1 to 21 (dietary treatment period) and wk 1 to 9 (duration of experiment). (A) Effects of high $(26.2 \%)$ versus low $(21.5 \%)$ starch fed during wk 1 to 9. Overall effects of starch content: $P=0.002$ during $\mathrm{d} 1$ to 21 and $P=0.09$ during wk 1 to 9 ; interaction of starch content $\times$ time: $P=$ 0.95 for $\mathrm{d} 1$ to 21 and $P=0.92$ for wk 1 to 9 . (B) Effects of monensin supplementation (0 vs. $400 \mathrm{mg} / \mathrm{d}$ prepartum and $450 \mathrm{mg} / \mathrm{d}$ postpartum). Overall effect of monensin: $P=0.94$ prepartum, $P=0.69$ for $\mathrm{d}$ 1 to 21 , and $P=0.29$ for wk 1 to 9 ; interaction of monensin $\times$ time: $P$ $=0.19$ prepartum, $P=0.21$ for $\mathrm{d} 1$ to 21 , and $P=0.38$ for wk 1 to 9 . is likely because an increase in the concentration of succinyl CoA in the tricarboxylic acid cycle from increased propionate metabolism has inhibitory effects on 3-hydroxy-3-methylglutaryl CoA synthase synthesis (Zammit, 1990), which is the rate-limiting step in ketone body synthesis.

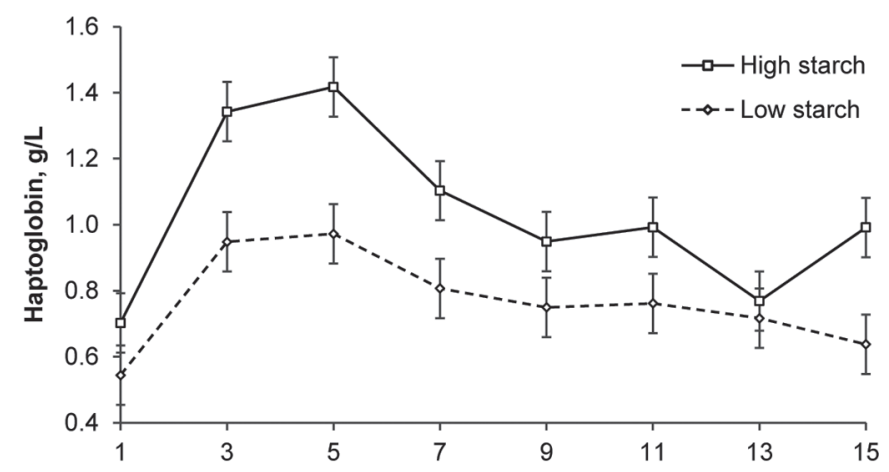

B

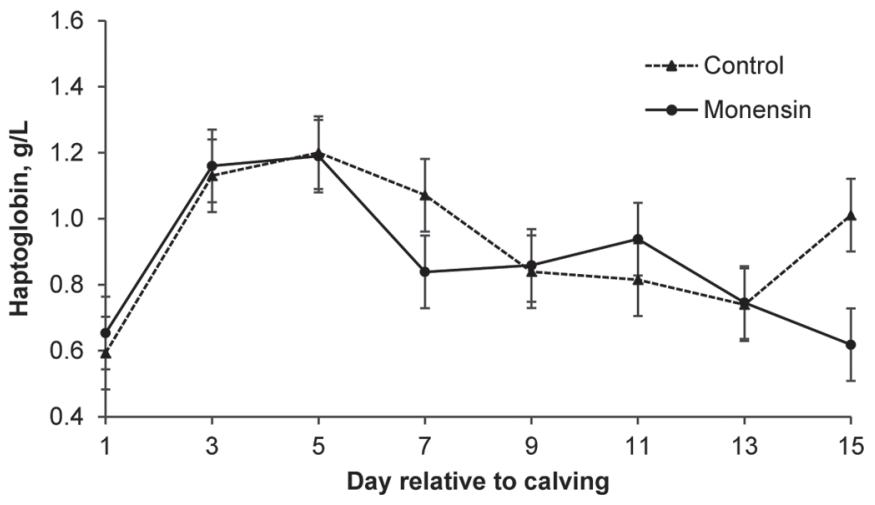

Figure 6. Least squares means $( \pm$ SEM) for plasma haptoglobin $(\mathrm{g} / \mathrm{L})$ for cows fed different starch content in the postpartum diet and monensin throughout the periparturient period. (A) Effects of high $(26.2 \%)$ versus low $(21.5 \%)$ starch fed during d 1 to 15 . Overall effect of starch content: $P=0.04$; interaction of starch content $\times$ day: $P=$ 0.48. (B) Effects of monensin supplementation $(0$ vs. $400 \mathrm{mg} / \mathrm{d}$ prepartum and $450 \mathrm{mg} / \mathrm{d}$ postpartum). Overall effect of monensin: $P=0.70$; interaction of monensin $\times$ day: $P=0.37$. 
Table 6. Health events for cows fed high- or low-starch diets during the first 3 wk postpartum and control or monensin treatments throughout the periparturient period and into early lactation ${ }^{1}$

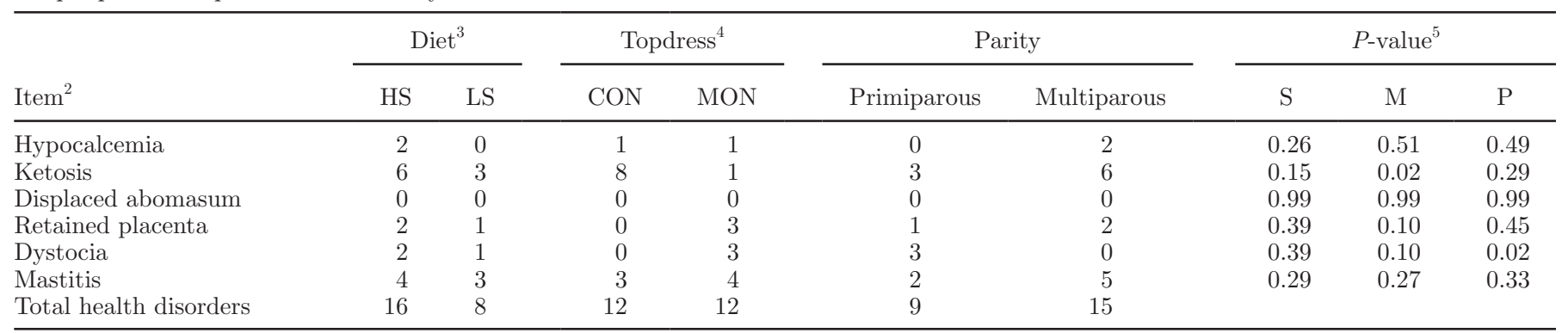

${ }^{1}$ Health events for cows that remained in the final data set.

${ }^{2}$ Disorders defined as follows: hypocalcaemia = cows that had decreased body temperature and were unable to stand were treated with calcium dextrose; ketosis = cows that had rapid decreases in milk production and DMI were checked with Precision Xtra (Abbott Laboratories, Abbott Park, IL) blood meter; readings $\geq 2.6 \mathrm{mmol} / \mathrm{L}$ were treated with dextrose and propylene glycol; displaced abomasum = movement of the fourth compartment of the stomach to a location on the right or left side of the cow and detected by auscultating a "ping" sound with finger percussion; retained placenta $=$ cows that retained afterbirth for $>24 \mathrm{~h}$; dystocia $=$ cows that had a calving ease score of $>3$; mastitis $=$ cows with abnormal milk, or inflamed quarter were treated with antibiotics.

${ }^{3}$ Postpartum diets: HS = high-starch diet $(26.2 \%$ starch $)$; LS = low-starch diet $(21.5 \%$ starch $)$.

${ }^{4} \mathrm{CON}=$ control topdress (formulated to supplement $0 \mathrm{mg} / \mathrm{d}$ monensin); MON = monensin topdress (formulated to supplement $400 \mathrm{mg} / \mathrm{d}$ prepartum and $450 \mathrm{mg} / \mathrm{d}$ postpartum).

${ }^{5} \mathrm{~S}=$ starch, $\mathrm{M}=$ monensin, and $\mathrm{P}=$ parity.

The removal of oxaloacetate from the tricarboxylic acid cycle to phosphoenolpyruvate for gluconeogenesis is a cataplerotic reaction (Owen et al., 2002). During gluconeogenesis, additional oxaloacetate must be supplied to condense with acetyl CoA to maintain tricarboxylic acid cycle function and generate ATP. During the early postpartum period, there is an increase in the activity of pyruvate carboxylase (Greenfield et al., 2000), which is a key anaplerotic enzyme in the tricarboxylic acid cycle (Owen et al., 2002). It is likely that additional oxaloacetate entering the tricarboxylic acid cycle during early lactation originates from amino acids and lactate. Although propionate likely supplies some oxaloacetate for oxidation, it is preferentially used for gluconeogenesis during this early lactation period (Drackley et al., 2001). Andersen et al. (2002) reported increased capacity for palmitate conversion to $\mathrm{CO}_{2}$ in liver slices from early-lactation cows fed more propiogenic diets compared with liver slices from cows fed less propiogenic diets, suggesting that feeding more propiogenic diets promotes more complete oxidation of acetyl CoA derived from mitochondrial $\beta$-oxidation of fatty acyl CoA. Accordingly, cows fed HS and cows fed MON in the current study had lower plasma BHBA concentrations in early lactation. Whereas both Andersen et al. (2004) and Rabelo et al. (2005) observed no difference between treatments for plasma NEFA, cows fed higher energy postpartum diets had lower plasma BHBA concentrations. Mullins et al. (2012) similarly observed that cows fed monensin had decreased plasma BHBA postpartum.
In the current study, we observed greater increases in plasma glucose and reductions in plasma BHBA for primiparous cows fed MON compared with multiparous cows fed MON; however, increases in early-lactation DMI and milk production were observed for all cows regardless of parity, as indicated by a lack of MON $\times$ parity interactions for these measures (McCarthy et al., 2015). Relatively few other studies have evaluated the effects of parity with monensin treatment for comparison with the observations in the current study. Melendez et al. (2004) similarly observed greater reductions in plasma BHBA in primiparous cows administered a prepartum controlled-release capsule of monensin; however, milk and intake data were not reported. Arieli et al. (2008) studied primiparous cows and observed faster increases in early-lactation milk in both monensin treated primiand multiparous cows; however, they did not report monensin $\times$ parity interactions for plasma metabolites. Arieli et al. (2008) also noted that the cases of clinical ketosis treatment were lower in monensin-treated cows compared to controls ( 8 vs. $21 \%$ ). In the current study, cows fed HS tended to have less subclinical ketosis than cows fed LS and cows fed MON had less subclinical ketosis and also had fewer clinical cases of ketosis, likely from increased propionate supply to the liver. Interestingly, ketotic cows may also have a reduced ability for $\beta$-oxidation of NEFA as indicated by decreased mRNA levels of carnitine palmitoyl-transferase (CPT)-I and decreased mRNA and protein levels of CPT-II, acylCoA dehydrogenase long chain, 3-hydroxy-3-methylglutaryl CoA synthase, and acetyl CoA carboxylase 
Table 7. Liver composition at $7 \mathrm{~d}( \pm 1.6 \mathrm{SD})$ postpartum for cows fed high- or low-starch diets during the first 3 wk postpartum and control or monensin treatments throughout the periparturient period and into early lactation

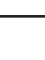

(20)

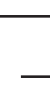

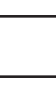

Liver glycogen, $\%$ of wet weight
Pight

$\begin{array}{llc}\text { HS } & \text { LS } & \text { SEM } \\ 6.68 & 5.97 & 1.0 \\ 0.90 & 0.80 & 0.1\end{array}$

\begin{tabular}{ccc} 
& CON & MON \\
\hline .09 & 6.56 & 6.08
\end{tabular}

SEM

$\begin{array}{ll}0.77 & 0.93\end{array}$

${ }^{1}$ Postpartum diets: HS = high-starch diet (26.2\% starch); LS = low-starch diet (21.5\% starch).

${ }^{2} \mathrm{CON}=$ control topdress (formulated to supplement $0 \mathrm{mg} / \mathrm{d}$ monensin); MON = monensin topdress (formulated to supplement $400 \mathrm{mg} / \mathrm{d}$ prepartum and $450 \mathrm{mg} / \mathrm{d}$ postpartum) ${ }^{3} \mathrm{~S}=$ starch, $\mathrm{M}=$ monensin, and $\mathrm{P}=$ parity.

Table 8. Conversion of $\left[1-{ }^{14} \mathrm{C}\right]$ propionate $[\mu \mathrm{mol} /(\mathrm{g}$ of wet weight $\times \mathrm{h})]$ to $\mathrm{CO}_{2}$ and glucose$[\mu \mathrm{mol} /(\mathrm{g}$ wet weight $\times \mathrm{h})]$ on $\mathrm{d} 7( \pm 1.6 \mathrm{SD})$ postpartum for cows fed varying content of starch and monensin throughout the periparturient period and into early lactation

\begin{tabular}{|c|c|c|c|c|c|c|c|c|c|c|c|c|}
\hline \multirow[b]{2}{*}{ Item } & \multicolumn{2}{|c|}{$\operatorname{Diet}^{1}$} & \multirow[b]{2}{*}{ SEM } & \multicolumn{2}{|c|}{ Topdress $^{2}$} & \multirow[b]{2}{*}{ SEM } & \multicolumn{6}{|c|}{$P$-value ${ }^{3}$} \\
\hline & HS & LS & & $\mathrm{CON}$ & MON & & $\mathrm{S}$ & M & $\mathrm{P}$ & $\mathrm{S} \times \mathrm{M}$ & $\mathrm{S} \times \mathrm{P}$ & $\mathrm{M} \times \mathrm{P}$ \\
\hline $\mathrm{CO}_{2}$ & 6.13 & 6.40 & 0.37 & 6.38 & 6.16 & 0.37 & 0.58 & 0.66 & 0.04 & 0.82 & 0.29 & 0.69 \\
\hline Glucose & 4.04 & 4.40 & 0.31 & 3.90 & 4.53 & 0.31 & 0.40 & 0.14 & 0.01 & 0.39 & 0.22 & 0.30 \\
\hline Glucose: $\mathrm{CO}_{2}$ ratio & 0.66 & 0.67 & 0.04 & 0.61 & 0.72 & 0.05 & 0.97 & 0.05 & 0.40 & 0.58 & 0.79 & 0.30 \\
\hline
\end{tabular}

${ }^{1}$ Postpartum diets: HS = high-starch diet (26.2\% starch); LS = low-starch diet (21.5\% starch).

${ }^{2} \mathrm{CON}=$ control topdress (formulated to supplement $0 \mathrm{mg} / \mathrm{d}$ monensin); MON = monensin topdress (formulated to supplement $400 \mathrm{mg} / \mathrm{d}$ prepartum and $450 \mathrm{mg} / \mathrm{d}$ postpartum). ${ }^{3} \mathrm{~S}=$ starch, $\mathrm{M}=$ monensin, $\mathrm{P}=$ parity. 
at increasing serum BHBA concentrations ( $\mathrm{Li}$ et al., 2012), indicating further impairment in hepatic NEFA handling when ketone synthesis is elevated.

Propionate is a potent insulin secretagogue, likely because propionate production increases rapidly following meal consumption (Brockman, 1990). In the current study, cows fed HS had increased plasma insulin concentrations. Andersen et al. (2004) and Rabelo et al. (2005) observed similar increases in plasma insulin for cows fed higher-energy propiogenic diets postpartum compared with cows fed lower-energy diets. In early lactation, the relatively low circulating insulin concentrations and peripheral tissue insulin resistance may help to attenuate the gluconeogenic contribution from other glucose precursors and increase liver glucose output (Drackley et al., 2001). Postpartum cows decrease whole-body glucose oxidation to conserve glucose for milk lactose synthesis (Bell et al., 2000). In the current study, cows fed HS had increased insulin concentrations and exhibited increased insulin resistance, as indicated by a lower RQUICKI. This increase in insulin resistance along with increases in early-lactation milk yield (McCarthy et al., 2015) would suggest a greater increase in glucose availability for the mammary gland in cows fed HS.

During the immediate postpartum period, there is an increase in inflammation (Sordillo and Raphael, 2013). Cytokines that are produced by immune cells can elicit an inflammatory response and include the release of acute phase proteins from the liver, such as haptoglobin. Increased plasma haptoglobin is known to be a marker of postpartum inflammation in dairy cows (Humblet et al., 2006). In the current study, cows that were fed HS had elevated haptoglobin during the immediate postpartum period compared with LS cows, although, because haptoglobin is a nonspecific marker, the exact cause of this inflammation is unknown. However, because the HS diet in the current study was more fermentable than the LS diet (21.9 vs. $17.1 \%$ of DM as fermentable starch; McCarthy et al., 2015), we speculate that cows fed HS might have been experiencing a state of postpartum ruminal transition, leading to increased inflammation and elevated haptoglobin concentrations. Penner et al. (2007) observed that primiparous cows experienced the occurrence of mild ruminal acidosis $(5.8<\mathrm{pH}>5.5)$ during $\mathrm{d} 1$ to 5 postpartum that was greater than during the prepartum period, whereas Iqbal et al. (2010) observed increased haptoglobin concentrations in late-lactation cows that were fed starch that was more rumen degradable. Although cows fed HS had increased haptoglobin concentrations in the current study, the overall effects of HS diet in the current study on production performance (McCarthy et al., 2015) and energy metabolism were positive.
The bovine liver has limited capacity for triglyceride export compared with that of monogastric animals (Chilliard, 1993), and the export of triglycerides is a rate-limiting step in hepatic NEFA metabolism. Some lipid accumulation in the liver during the periparturient period seems to be a normal adaptation to lactation (Grum et al., 1996); however, excess liver triglyceride accumulation has been shown to decrease the ability of the hepatocyte to synthesize urea (Strang et al., 1998). The consequent increase in liver ammonia might decrease glucose synthesis from propionate (Overton et al., 1999). In the current study, we found no effect of starch content on liver triglyceride content, although Andersen et al. (2004) observed that cows fed higher-energy propiogenic diets had decreased liver triglyceride content. Although elevated hepatic triglyceride accumulation in transition cows has been shown to have negative effects on gluconeogenesis in multiparous cows, the effect of triglyceride content in primiparous cows may not be as deleterious. In the current study, primiparous cows fed MON had increased liver triglyceride content compared with $\mathrm{CON}$ primiparous cows, although overall metabolism and energy balance would indicate positive effects of MON treatment on primiparous cows. The observed increase in plasma glucose concentration with MON treatment was driven mainly by a MON $\times$ parity interaction, and we observed a decrease in plasma BHBA concentration with MON, which was again mainly driven by decreases in primiparous cows. The MON-treated primiparous cows likely had more glucose synthesis and decreased ketone body synthesis. However, we did not observe any treatment difference in plasma NEFA concentration, so it is likely that there was no difference in uptake of NEFA by the liver. Because there was likely less hepatic ketone synthesis in MON-treated primiparous cows, more of the NEFA taken up by the liver was likely reesterified into triglyceride. Because VLDL export is the rate-limiting step in hepatic fatty acid export, MON-treated primiparous cows likely had increased triglyceride accumulation in the liver. Mullins et al. (2012) observed no difference in postpartum liver triglyceride content, although cows fed monensin had increased CPT-1 mRNA abundance immediately pre- and postpartum, indicating that perhaps cows fed monensin had increased capacity to oxidize fatty acids, as the entry of fatty acyl CoA into the mitochondria is regulated by CPT-I and is a major control point in the mitochondrial $\beta$-oxidation of fatty acids (Drackley, 1999). This would be in accordance with the observations of Andersen et al. (2002): that the increased hepatic supply of propionate from feeding diets of greater propiogenic capacity resulted in increased capacity for in vitro conversion of palmitate to $\mathrm{CO}_{2}$. 
In experiments using labeled isotopes, the $\left[1-{ }^{14} \mathrm{C}\right]$ propionate label randomizes in the tricarboxylic acid cycle such that every mole of $\left[1-{ }^{14} \mathrm{C}\right]$ propionate that is directed toward oxaloacetate would yield 0.5 moles of radiolabeled $\mathrm{CO}_{2}$ and 0.5 moles of radiolabeled glucose (Knapp et al., 1992). Therefore, any increase in this ratio of labeled glucose to $\mathrm{CO}_{2}$ would suggest an increase in the efficiency of utilization of propionate for gluconeogenesis. In the current study, cows treated with monensin had an increase in the ratio of glucose to $\mathrm{CO}_{2}$, likely from an increase in propionate supply, indicating an increased propensity to convert propionate to glucose with increased propionate supply. It appears that in the early-lactation cow, when there is an increase in propionate supply to the liver, there is an increased propensity to convert propionate to glucose rather than oxidize it (Drackley et al., 2001). The rates of gluconeogenesis from $\left[1-{ }^{14} \mathrm{C}\right]$ propionate in early-lactation liver slices are increased compared with rates in liver slices from the same cows once they have reached mid lactation (Aiello et al., 1989). Drackley et al. (2001) observed a positive correlation between carbohydrate intake in the immediate postpartum period with the efficiency of $\left[1-{ }^{14} \mathrm{C}\right]$ propionate conversion to glucose in liver slices, which would suggest that the liver has the capacity to direct additional propionate toward glucose during this time. In the current study, starch had no effect on the ratio of glucose to $\mathrm{CO}_{2}$. However, because we biopsied cows at $d 7( \pm 1.6 \mathrm{SD})$ postpartum and increases in DMI in HS cows were not observed until d 14 (McCarthy et al., 2015), starch intake had likely not increased sufficiently at the time of biopsy. Although in vitro $\left[1-{ }^{14} \mathrm{C}\right]$ palmitate metabolism was not measured in the current study, Andersen et al. (2002) observed that cows fed higher-energy propiogenic diets in early lactation had increased capacity in vitro for conversion of palmitate to $\mathrm{CO}_{2}$ compared with cows fed lower-energy diets. Increased mitochondrial $\beta$-oxidation of fatty acyl CoA would generate ATP to support increased gluconeogenesis from propionate.

\section{CONCLUSIONS}

Overall effects of feeding a higher-starch diet on metabolism appear to be positive, as shown by increased plasma glucose and insulin concentrations and decreased plasma NEFA and BHBA concentrations in early lactation. Cows fed monensin during the peripartal period had an increased propensity to convert propionate to glucose in vitro as well as increased concentrations of plasma glucose and reduced concentrations of plasma BHBA, resulting in reduced subclinical ketosis. In conclusion, cows fed more propiogenic diets during the early-lactation period from either increased starch content or inclusion of monensin had improved postpartum energy status.

\section{ACKNOWLEDGMENTS}

The authors sincerely appreciate and gratefully acknowledge the assistance of G. Birdsall and the staff at the Cornell University Dairy Teaching and Research Center for their care of the cows on study as well as the undergraduate research assistance of E. Martens, R. Foley, K. Brust, and A. Forstater. We sincerely appreciate the assistance of W. Leonard and K. Fitch at Cornell Environmental Health and Safety and S. Lamb at the Cornell Animal Health Diagnostic Center for graciously allowing us the use of their laboratory equipment. The authors also gratefully acknowledge Elanco Animal Health (Greenfield, IN) for partial financial support of this study.

\section{REFERENCES}

Aiello, R. J., L. E. Armentano, S. J. Bertics, and A. T. Murphy. 1989. Volatile fatty acid uptake and propionate metabolism in ruminant hepatocytes. J. Dairy Sci. 72:942-949.

Allen, M. S., B. J. Bradford, and M. Oba. 2009. BOARD-INVITED REVIEW: The hepatic oxidation theory of the control of feed intake and its application to ruminants. J. Anim. Sci. 87:3317-3334.

Andersen, J. B., N. C. Friggens, T. Larsen, M. Vestergaard, and K. L. Ingvartsen. 2004. Effect of energy density in the diet and milking frequency on plasma metabolites and hormones in early lactation dairy cows. J. Vet. Med. A Physiol. Pathol. Clin. Med. 51:52-57.

Andersen, J. B., N. C. Friggens, K. Sejrsen, M. T. Sørensen, L. Munksgaard, and K. L. Ingvartsen. 2003. The effects of low vs. high concentrate level in the diet on performance in cows milked two or three times daily in early lactation. Livest. Prod. Sci. 81:119-128.

Andersen, J. B., T. Larsen, M. O. Nielsen, and K. L. Ingvartsen. 2002. Effect of energy density in the diet and milking frequency on hepatic long chain fatty acid oxidation in early lactating dairy cows. J. Vet. Med. A Physiol. Pathol. Clin. Med. 49:177-183.

Arieli, A., U. Dicken, I. Dagoni, Y. Spirer, and S. Zamwel. 2008. Production and health of cows given monensin prepartum and a highenergy diet postpartum. J. Dairy Sci. 91:1845-1851.

Armentano, L. E., and J. W. Young. 1983. Production and metabolism of volatile fatty acids, glucose and $\mathrm{CO}_{2}$ in steers and the effects of monensin on volatile fatty acid kinetics. J. Nutr. 113:1265-1277.

Azain, M. J., and T. Kasser. 1999. A method for the determination of glucose synthesis in isolated bovine hepatocytes. J. Nutr. Biochem. 10:205-209.

Bauman, D. E., and W. B. Currie. 1980. Partitioning of nutrients during pregnancy and lactation: a review of mechanisms involving homeostasis and homeorhesis. J. Dairy Sci. 63:1514-1529.

Bell, A. W., W. S. Burhans, and T. R. Overton. 2000. Protein nutrition in late pregnancy, maternal protein reserves and lactation performance in dairy cows. Proc. Nutr. Soc. 59:119-126.

Bernal-Santos, G., J. W. Perfield, D. M. Barbano, D. E. Bauman, and T. R. Overton. 2003. Production responses of dairy cows to dietary supplementation with conjugated linoleic acid (CLA) during the transition period and early lactation. J. Dairy Sci. 86:3218-3228.

Brockman, R. P. 1990. Effect of insulin on the utilization of propionate in gluconeogenesis in sheep. Br. J. Nutr. 64:95-101.

Chilliard, Y. 1993. Dietary fat and adipose tissue metabolism in ruminants, pigs, and rodents: A review. J. Dairy Sci. 76:3897-3931.

Drackley, J. K. 1999. Biology of dairy cows during the transition period: The final frontier? J. Dairy Sci. 82:2259-2273. 
Drackley, J. K., T. R. Overton, and G. N. Douglas. 2001. Adaptations of glucose and long-chain fatty acid metabolism in liver of dairy cows during the periparturient period. J. Dairy Sci. 84(E. Suppl.):E100-E112.

Duffield, T. F., A. R. Rabiee, and I. J. Lean. 2008a. A meta-analysis of the impact of monensin in lactating dairy cattle. Part 1. Metabolic effects. J. Dairy Sci. 91:1334-1346.

Duffield, T. F., A. R. Rabiee, and I. J. Lean. 2008b. A meta-analysis of the impact of monensin in lactating dairy cattle. Part 2. Production effects. J. Dairy Sci. 91:1347-1360.

Duffield, T. F., A. R. Rabiee, and I. J. Lean. 2008c. A meta-analysis of the impact of monensin in lactating dairy cattle. Part 3. Health and reproduction. J. Dairy Sci. 91:2328-2341.

Fletcher, M. J. 1968. A colorimetric method for estimating serum triglycerides. Clin. Chim. Acta 22:393-397.

Folch, J., M. Lees, and G. H. Sloane-Stanley. 1957. A simple method for the isolation and purification of total lipids from animal tissues. J. Biol. Chem. 226:497-509.

Foster, L. B., and R. T. Dunn. 1973. Stable reagents for determination of serum triglycerides by a colorimetric Hantzsch condensation method. Clin. Chem. 19:338-340.

Greenfield, R. B., M. J. Cecava, and S. S. Donkin. 2000. Changes in mRNA expression for gluconeogenic enzymes in liver of dairy cattle during the transition to lactation. J. Dairy Sci. 83:1228-1236.

Grum, D. E., J. K. Drackley, L. R. Hansen, and J. D. Cremin Jr. 1996. Production, digestion, and hepatic lipid metabolism of dairy cows fed increased energy from fat or concentrate. J. Dairy Sci. 79:1836-1849.

Holtenius, P., and K. Holtenius. 2007. A model to estimate insulin sensitivity in dairy cows. Acta Vet. Scand. 49:29-31.

Humblet, M. F., H. Guyot, B. Boudry, F. Mbayahi, C. Hanzen, F. Rollin, and J. M. Godeau. 2006. Relationship between haptoglobin, serum amyloid A, and clinical status in a survey of dairy herds during a 6-month period. Vet. Clin. Pathol. 35:188-193.

Ingvartsen, K. L., and J. B. Andersen. 2000. Integration of metabolism and intake regulation: A review focusing on periparturient animals. J. Dairy Sci. 83:1573-1597.

Iqbal, S., Q. Zebeli, A. Mazzolari, S. M. Dunn, and B. N. Ametaj. 2010. Feeding rolled barley grain steeped in lactic acid modulated energy status and innate immunity in dairy cows. J. Dairy Sci. 93:5147-5156.

Knapp, J. R., H. C. Freetly, B. L. Reis, C. C. Calvert, and R. L. Baldwin. 1992. Effects of somatotropin and substrates on patterns of liver metabolism in lactating dairy cattle. J. Dairy Sci. 75:1025-1035.

Li, P., X. B. Li, S. X. Fu, C. C. Wu, X. X. Wang, G. J. Yu, M. Long, Z. Wang, and G. W. Liu. 2012. Alterations of fatty acid $\beta$-oxidation capability in the liver of ketotic cows. J. Dairy Sci. 95:1759-1766.

Littell, R. C., G. A. Milliken, W. W. Stroup, and R. D. Wolfinger 1996. SAS System of Mixed Models. SAS Institute, Cary, NC.

McCarthy, M. M., T. Yasui, C. M. Ryan, G. D. Mechor, and T. R. Overton. 2015. Performance of early-lactation dairy cows as affected by dietary starch and monensin supplementation. J. Dairy Sci. 98:3335-3350. 10.3168/jds.2014-8820.

Melendez, P., J. P. Goff, C. A. Risco, L. F. Archbald, R. Littell, and G. A. Donovan. 2004. Effect of a monensin controlled-release capsule on rumen and blood metabolites in Florida Holstein transition cows. J. Dairy Sci. 87:4182-4189.

Mullins, C. R., L. K. Mamedova, M. J. Brouk, C. E. Moore, H. B. Green, K. L. Perfield, J. F. Smith, J. P. Harner, and B. J. Bradford. 2012. Effects of monensin on metabolic parameters, feeding behavior, and productivity of transition dairy cows. J. Dairy Sci. 95:1323-1336.

Ospina, P. A., D. V. Nydam, T. Stokol, and T. R. Overton. 2010. Association between the proportion of sampled transition cows with increased nonesterified fatty acids and beta-hydroxybutyrate and disease incidence, pregnancy rate, and milk production at the herd level. J. Dairy Sci. 93:3595-3601.

Overton, T. R., J. K. Drackley, C. J. Ottemann-Abbamonte, A. D Beaulieu, L. S. Emmert, and J. H. Clark. 1999. Substrate utilization for hepatic gluconeogenesis is altered by increased glucose demand in ruminants. J. Anim. Sci. 77:1940-1951.

Owen, O. E., S. C. Kalhan, and R. W. Hanson. 2002. The key role of anaplerosis and cataplerosis for citric acid cycle function. J. Biol. Chem. 277:30409-30412.

Penner, G. B., K. A. Beauchemin, and T. Mutsvangwa. 2007. Severity of ruminal acidosis in primiparous Holstein cows during the periparturient period. J. Dairy Sci. 90:365-375.

Piepenbrink, M. S., A. L. Marr, M. R. Waldron, W. R. Butler, T. R. Overton, M. Vázquez-Añón, and M. D. Holt. 2004. Feeding 2-hydroxy-4-(methylthio)-butanoic acid to periparturient dairy cows improves milk production but not hepatic metabolism. J. Dairy Sci. 87:1071-1084.

Rabelo, E., R. L. Rezende, S. J. Bertics, and R. R. Grummer. 2003. Effects of transition diets varying in dietary energy density on lactation performance and ruminal parameters of dairy cows. J. Dairy Sci. 86:916-925.

Rabelo, E., R. L. Rezende, S. J. Bertics, and R. R. Grummer. 2005. Effects of pre- and postfresh transition diets varying in dietary energy density on metabolic status of periparturient dairy cows. J. Dairy Sci. 88:4375-4383.

Reynolds, C. K., P. C. Aikman, B. Lupoli, D. J. Humphries, and D. E. Beever. 2003. Splanchnic metabolism of dairy cows during the transition from late gestation through early lactation. J. Dairy Sci. 86:1201-1217.

Sordillo, L. M., and W. Raphael. 2013. Significance of metabolic stress, lipid mobilization, and inflammation on transition cow disorders. Vet. Clin. North Am. Food Anim. Pract. 29:267-278.

Strang, B. D., S. J. Bertics, R. R. Grummer, and L. E. Armentano. 1998. Effect of long-chain fatty acids on triglyceride accumulation gluconeogenesis, and ureagenesis in bovine hepatocytes. J. Dairy Sci. 81:728-739.

Veenhuizen, J. J., J. K. Drackley, M. J. Richard, T. P. Sanderson, L. D. Miller, and J. W. Young. 1991. Metabolic changes in blood and liver during development and early treatment of experimental fatty liver and ketosis in cows. J. Dairy Sci. 74:4238-4253.

Vernon, R. G. 2005. Lipid metabolism during lactation: A review of adipose tissue-liver interactions and the development of fatty liver. J. Dairy Res. 72:460-469

Zammit, V. A. 1990. Ketogenesis in the liver of ruminants-Adaptations to a challenge. J. Agric. Sci. (Camb.) 115:155-162. 